
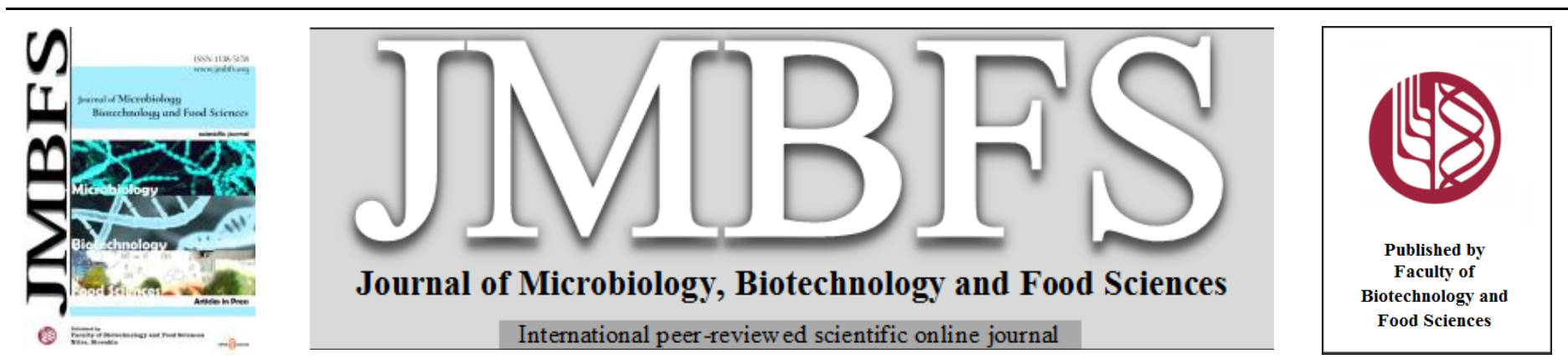

\title{
DEVELOPMENT OF A VEGAN SAUSAGE WITH YOUNG GREEN JACKFRUIT, OYSTER MUSHROOM, AND COCONUT FLOUR AS AN ENVIRONMENTALLY FRIENDLY PRODUCT WITH CLEANER PRODUCTION APPROACH
}

\author{
Iranga Paranagama*1, Indira Wickramasinghe ${ }^{1}$, Dulani Somendrika ${ }^{1}$, Kasun Benaragama $^{2}$ \\ Address(es): \\ ${ }^{1}$ Department of Food Science and Technology, Faculty of Applied Sciences, University of Sri Jayewardenepura, Nugegoda, Sri Lanka, +94776067286 \\ ${ }^{2}$ Wild Rescue Team, 25A, Araliya Uyana, Kalutara, Sri Lanka.
}

*Corresponding author: iranga.thejana.pd@gmail.com

https://doi.org/10.55251/jmbfs.4029

\section{ARTICLE INFO}

Received 2. 12. 2020

Revised 15. 9. 2021

Accepted 21. 9. 2021

Published 1. 2. 2022

Regular article open $\mathcal{O}_{\text {access }}$

\begin{abstract}
Veganism or vegetarianism is a trending topic in the modern world. Natural disasters, climate change, and pandemics lead people towards healthier and plant-based diets and nature-friendly lifestyle. Higher meat consumption has led the world into a huge struggle resulting in global warming, rising sea levels, disease spreading like swine flu, bird flu, coronavirus, etc. The main objective of this research was to develop a socially responsible vegan product, minimizing its environmental impact with a cleaner production approach. Generally, many vegan products are produced using soy as the main ingredient, but it is the second-largest agricultural driver of deforestation globally. Currently, there are no significant studies done on vegan product development considering the environmental impact and cleaner production. Concerning all these objectives, this vegan sausage was developed with young green jackfruit (Artocarpus heterophyllus), oyster mushrooms (Pleurotus ostreatus), and coconut flour (Cocos nucifera Lin.) as main ingredients. This product was subjected to sensory evaluation, proximate analysis using AOAC and SLS methods, and microbiological analysis. The moisture, ash, total fat, crude protein, and crude fibre contents of the product were $64.49 \pm 0.16 \%, 2.62 \pm 0.18 \%, 5.94 \pm 0.25 \%, 3.95 \pm 0.30 \%$ and $1.22 \pm 0.16 \%$ respectively. Total carbohydrate value and energy profiles were $21.78 \pm 0.38 \%$ and $156.3 \mathrm{kcal} / 100 \mathrm{~g}$ calculated according to the Codex Guideline on Nutrition Labelling. Following a cleaner production approach helped to identify that it is more environmentally friendly using electricity than LPG in Sri Lanka for this kind of product development and to reduce the total $\mathrm{CO}_{2}$ emission per $\mathrm{kg}$ of vegan sausage from $0.678 \mathrm{~kg} \mathrm{CO}_{2} / \mathrm{kg}$ to $0.477 \mathrm{~kg} \mathrm{CO} / \mathrm{kg}$.
\end{abstract}

Keywords: Cleaner Production Approach, Environmental Impact, Soy Driven Deforestation, Vegan Product Development, Vegan Sausage

\section{INTRODUCTION}

In the modern world, being vegan or vegetarian has become a trend. Vegetarianism and veganism are dietary patterns that are followed by many people and trends in the modern world. Because of the range of food options available and the numerous factors that drive individuals to follow such practices, vegetarian and vegan dietary patterns can be quite diverse (Melina et al., 2016). This food culture has been raised due to various reasons including concern about animal welfare, environmental sustainability, and personal health (Ruby, 2012). In some countries as India and Sri, Lanka people follow this culture due to their religious beliefs. In vegan culture, they avoid all, that cause any harm to animal welfare like wearing fur, leather, and using cosmetics and other products that are tested on animals

According to studies, approximately $8 \%$ of Canadians, $3 \%$ of Americans, $2 \%$ of New Zealanders, $3 \%$ of Australians, $3 \%$ of Britons, $6 \%$ of Irish, $9 \%$ of Germans, 8.5 percent of Israelis, and approximately $40 \%$ of Indians practice a vegetarian or vegan lifestyle. (Ruby, 2012). Also, this community is increasing day by day and it can be predicted that a good demand will be there for a healthy vegan product.

Product development is a wide area that is discussed always in the developing world. Now, developing a sustainable and responsible product has become a major requirement of the society. A product that provides environmental, social, and economic benefits while protecting public health and the environment over the product life cycle can be considered as a sustainable product (World Economic Forum, 2020). This concept is not only for ecologists and naturalists but for all the sectors including social, political, economic, and managerial scientists and professionals (De Medeiros et al., 2014). It is essential to meet both the titles "Sustainability" and "Product Development", then it will be an ECO design or a responsible product. In that case, many areas were considered as cleaner production, green product development, ECO-friendly product development, and sustainable product development.
To socialize this concept a vegan sausage was developed using young green jackfruit (Artocarpus heterophyllus), oyster mushrooms (Pleurotus ostreatus), and coconut flour (Cocos nucifera Lin.) considering ecological value, popularity among people as a meat substitute and relatively high protein contents of them. Also, some common ingredients like soy, which is usually used in sausage production and vegan food production, were eliminated after concerning the adverse environmental impact due to the cultivation of the ingredient. Usually, sausages are made from various types of meats. By selecting to develop a nonmeat sausage it is easier to give this concept to society.

A cleaner production approach was followed from the very beginning of this research. Cleaner production (CP) is an area used by industries and organizations which is directly connected with sustainability. It has been penetrating all the industries and much researches have been conducted on the development of clean technologies (Yi et al., 2001). The zero-waste concept can be considered as the ultimate goal of CP implementation (Pauli, 1997). CP approach creates a win-win situation for both the industries as well as the environment by acting as a management tool, an economic tool, an environmental tool, and a quality improvement tool. The main objective of this research was developing a sustainable and responsible product for the vegan community.

\section{MATERIAL AND METHODS}

\section{The Raw Materials}

In this vegan sausage development, as major ingredients young green jackfruit (Artocarpus heterophyllus) and American oyster mushrooms (Pleurotus ostreatus) were selected. The fresh young green jackfruit as whole fruit and mushrooms as retail packets were obtained from the local market and taken to the laboratory of the Department of Food Science and Technology, University of $\mathrm{Sri}$ 
Jayewardenepura, Sri Lanka. As minor ingredients gram flour, bread crumbs, coconut flour, rice flakes, cornflour, wheat flour, chilli powder, chilli flakes, pepper, curry powder, garlic powder, white coconut oil, salt, cellulose casings, and Low Density Polyethylene (LDPE) vacuum packaging were purchased from the local market and taken to the laboratory of the Department of Food Science and Technology, University of Sri Jayewardenepura, Sri Lanka.

\section{Processing Steps}

Initially, good quality young green jackfruit and American oyster mushrooms were selected followed by cleaning, washing, cutting into pieces and boiling for 20 minutes in water were carried out. Excess water was removed from the boiled ingredients and mincing was done. The minced ingredients, as well as other ingredients including fillers, binders, spices and oil, were weighted according to the vegan sausage formula. All the ingredients were mixed well manually, transferred into a sausage stuffer and stuffing was carried out. The stuffed sausages were tied using a manual sausage tying machine, steamed for 30 minutes, cooled in $5{ }^{\circ} \mathrm{C}$ water for 15 minutes, removed the casings, vacuum packaged and stored at $-4{ }^{\circ} \mathrm{C}$

Table 1 Young green jackfruit to mushroom ratios of the preliminary formula

\section{Statistical Analysis}

Preliminary studies and product formula optimization were analyzed using IBM Statistics 23 software package and the data in proximate analysis was analyzed using Minitab 19 software package.

\section{Preliminary Studies}

According to Sri Lankan Standards, (SLS 1218:2001) meat sausage should contain $60 \%$ of meat minimum. The percentage of meat in meat sausage recipe was replaced with a mixture of mushroom and young green jackfruit. But in this vegan sausage development, meat content was considered as $65 \%$. To decide young green jackfruit to mushroom ratio, a sensory analysis was carried out using Freidman tes in IBM SPSS statistics 23 software package. The formulas given in Table 1 were prepared using the traditional chicken sausage recipe in the preliminary stage.
Table 1 Young green jackfruit to mushroom ratios
Young green jackfruit: Oyster mushroom
Young green jackfruit $\%$ of the vegan sausage
Mushroom $\%$ of the vegan sausage

\begin{tabular}{cccc}
$\mathbf{2 0 : 8 0}$ & $\mathbf{4 0 : 6 0}$ & $\mathbf{6 0 : 4 0}$ & $\mathbf{8 0 : 2 0}$ \\
13 & 26 & 39 & 52 \\
52 & 39 & 26 & 13 \\
\hline
\end{tabular}

After selecting the young green jackfruit to mushroom ratio, several product prototypes were developed to get the final formula. Other ingredients like binders, fillers and spices of the basic formula that differ from traditional chicken sausage recipe, was decided after studying previous studies (Balasooriya, 2008; Balasooriya et al., 2011; Jayathilake, 2008; Liyanage, 2015) done on vegetarian sausages and the knowledge acquired from the sausage manufacturing industry in Sri Lanka.

\section{Preparation of Product Prototypes}

When developing product prototypes, several factors were used as experimental designs and shown below in Figure 1.

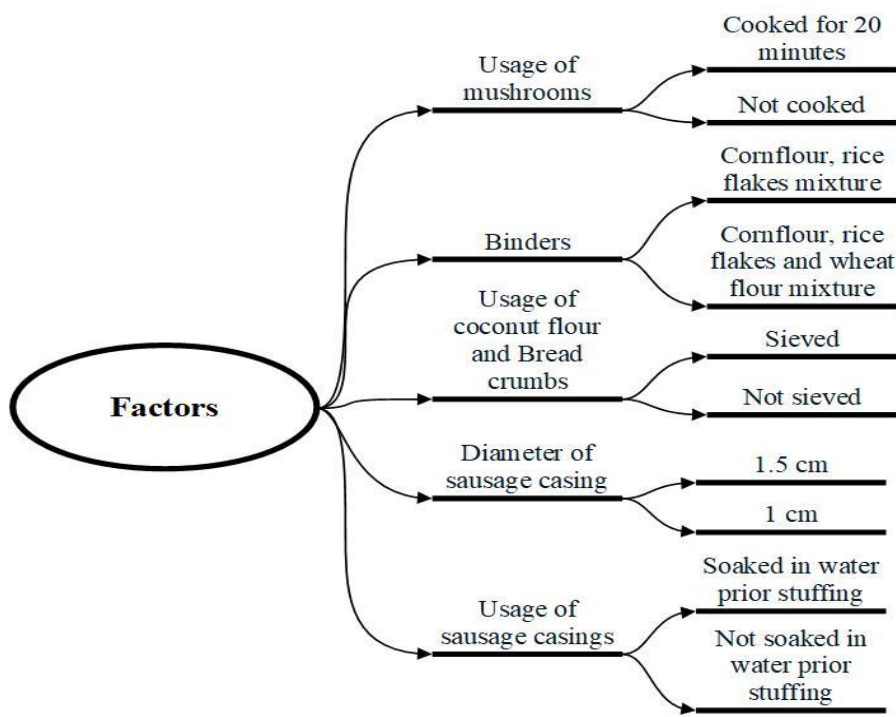

Figure 1 Experimental designs used in developing the vegan sausage formula

\section{Product Formula Optimization}

To optimize the vegan sausage, eight formulas were developed statistically using a three-factor factorial design. In the case of factorial design, salt content, coconut flour content, and pepper content were used as variables and two levels were used as high level and low level. A sensory evaluation was conducted using a five-point hedonic scale to evaluate the prepared samples according to the factorial design. As sensory characteristics appearance, texture, mouthfeel, odour, spiciness, saltiness, oiliness, overall taste, and overall acceptability were assessed. A semitrained sensory panel with 30 panellists was used to evaluate the final product formula. The evaluation was carried out according to the Friedman test using IBM SPSS statistics 23 software package. After evaluating the results of the sensory evaluation, the final vegan sausage formula was chosen.

\section{Proximate Analysis}

The proximate analysis was carried out to determine the moisture content by Association of Official Analytical Chemists (AOAC) method 925.10 (Oven Drying Method), ash content by AOAC method 923.03, salt content as $\mathrm{NaCl}$ by
Mohr's method, free fat content by Sri Lankan Standards (SLS) Method 779.1974 (Soxhlet Extraction Method), total fat content by the modified method of SánchezMachado (Sánchez-Machado et al., 2004), Crude protein content by AOAC method 984.13 (Kjeldahl Method), and Crude fiber content by SLS 28 part 8:2008

\section{Microbiological Analysis}

To determine the microbial quality of the vegan sausage, total plate count (TPC) according to SLS 516: part 1:1991, and yeast and mould count by SLS 516 part 2:1991 were carried out

\section{Cleaner Production Assessment}

In this vegan sausage development, the cleaner production methodology recommended by United Nations Industrial Development Organization (UNIDO) and United Nations Environmental Program (UNEP) (Nilson et al., 2007) and the methodology used in the studies carried out by Rahim and Raman (Rahim \& Raman, 2015) were followed after adapting it to this particular study by doing necessary adjustments using emission factors used in Sri Lanka (Table 2).

The total water consumption (equation 1), total electricity consumption (equation 2 ), total fuel consumption (equation 3 ), the total amount of solid waste and wastewater generated $(\mathrm{kg} / \mathrm{month})$ were calculated followed by the $\mathrm{CO}_{2}$ emission rate was calculated using the Intergovernmental Panel on Climate Change (IPCC) method (equation 4).

Total water consumption $\left(\mathrm{m}^{3} / \mathrm{month}\right)=$ Water used in process recipe + Water for cleaning activities + Water for domestic usage....(1)

Total electricity consumption $(\mathrm{kWh} /$ month $)=$ Electrical rating $(\mathrm{kW}) \times$ \{ Operating hours/day $\} \times$ \{no. of appliances $\} \times$ \{Total working days/month $\}. . .(2)$

Total fuel consumption $(\mathrm{kg} / \mathrm{month})=$ Fuel consumption rating $(\mathrm{kg} / \mathrm{hour}) \mathrm{x}$ Operating hours $\mathrm{x}$ \{no. of appliances $\mathrm{x}$ \{Total working days/month $\}$....(3)

$\mathrm{CO}_{2}$ emission = Entity data $\left(\mathrm{m}^{3}\right.$ of water, $\mathrm{kWh}$ of electricity, $\mathrm{L}$ of fuel, $\mathrm{kg}$ of solid waste and waste water) $\mathrm{x}$ Emission factor $\left(\mathrm{CO}_{2} / \mathrm{m}^{3}, \mathrm{CO}_{2} / \mathrm{kWh}, \mathrm{CO}_{2} / \mathrm{L}\right.$, $\left.\mathrm{CO}_{2} / \mathrm{kg}\right) \ldots .(4)$

Then according to the emission factors in Sri Lanka (Table 2), the total $\mathrm{CO}_{2}$ emission (equation 5) for the above five entities and the ecological

Total $\mathrm{CO}_{2}$ emission $(\mathrm{kg})=\sum$ (Entity data $\mathrm{x}$ Emission factor)....(5)

Table 2 Emission factors in Sri Lanka

\begin{tabular}{|c|c|c|c|}
\hline Entity & $\begin{array}{l}\text { Emission } \\
\text { factor }\end{array}$ & Unit & Reference \\
\hline Water & $*$ & $\mathrm{~kg} / \mathrm{m}^{3}$ & $\begin{array}{l}\text { (Ministry of Mahaweli } \\
\text { Development \& Environment, } \\
\text { 2016) }\end{array}$ \\
\hline Electricity & 0.58 & $\mathrm{~kg} / \mathrm{kWh}$ & $\begin{array}{l}\text { (Sri Lanka Sustainable Energy } \\
\text { Authority, 2017b) }\end{array}$ \\
\hline Fuel (LPG) & 2.73 & $\mathrm{~kg} / \mathrm{kg}$ & $\begin{array}{l}\text { (Sri Lanka Sustainable Energy } \\
\text { Authority, 2017a) }\end{array}$ \\
\hline Solid waste & 0.77 & $\mathrm{~kg} / \mathrm{kg}$ & (Awanthi \& Navaratne, 2018) \\
\hline Wastewater & 0.028 & $\mathrm{~kg} / \mathrm{m}^{3}$ & $\begin{array}{l}\text { (Central Environmental Authority } \\
\text { Sri Lanka, 2006) }\end{array}$ \\
\hline
\end{tabular}

Legend: ${ }^{*} \mathrm{CO}_{2}$ emission from water consumption is calculated by electricity consumption for pumping source to feeding point. According to National Water Supply and Drainage Board in Sri Lanka that value is $0.35 \mathrm{kWh} / \mathrm{m}^{3}$. 


\section{RESULTS AND DISCUSSION}

\section{Raw materials}

When selecting raw materials, ecological factors were considered due to the considerations of cleaner production. Young jackfruit adds more value to the developed vegan sausage as jackfruit has a higher ecological value and still underutilized (Ranasinghe et al., 2019). Both young green jackfruit and American oyster mushrooms are locally available and popular as meat substitutes in Sri Lanka and other countries as well.

Coconut flour is a byproduct of extracting virgin coconut oil (VCO) from the cold press method (Hossain, 2016). It is rich in proteins and fibre. So far coconut flour has been mainly used in the bakery industry (Gunathilake et al., 2009; Sivakami and Sarojini, 2013; Sridevi and Sarojini K.S., 2013; Hossain, 2016), but in this research also coconut flour was used after concerning the nutritional attributes of it.

Spices and condiments enhance the taste of the sausage and give some antimicrobial effects as well. In some researches done on sausage development has used fresh spices (Balasooriya, 2008; Jayathilake, 2008) but in this study spices like pepper, red chilli powder, red chilli flakes, curry powder, and garlic were used in dried and powdered form to get the unique taste of the sausage and it helps to maintain its shelf by reduced moisture content.

Generally, soy and soy derivatives are used in almost all the meat substitutes and many vegan products. When developing the vegan sausage, various steps have been followed to maintain the consistency of a responsible product. With that, after considering the environmental impact of soy (Thrane et al., 2017; World Wildlife Fund, 2020), it was not used to develop the vegan sausage, and soy was substituted by a mixture of wheat flour, cornflour, and powdered rice flakes which is popular among Sri Lankan as a breakfast meal. According to the World Wildlife Fund (WWF), extensive natural habitats are destroyed in many tropical countries to allow soybeans cultivation. Most of the rise in soy production in the last decade has occurred in Brazil, Argentina, Bolivia, and Paraguay, where production has done a significant impact on biodiversity hotspots like the Amazon rain forest by deforestation. Not only the threats to wild species, soybean cultivation is related to high rates of soil erosion, soil degradation, and compaction because the cultivation is highly mechanized. Also, the use of agrochemicals in large quantities pollutes rivers and lakes while unsustainable usage of water leads to strain aquifers. Various types of soy production generate greenhouse gases and it directly affects climate change because it happens on a very large scale (World Wildlife Fund, 2020).

To incorporate fat, white coconut oil was used over inexpensive palm oil because many studies reveal that oil palm cultivation leads to destroying tropical forests, habitat fragmentation, and greenhouse gas emissions (Fitzherbert et al., 2008 Saswattecha et al., 2015; Schrier-Uijl et al., 2013). Also, white coconut oil can be used to give a tender texture, moist mouthfeel, and lubricity to the vegan sausage (Żbikowska et al., 2020). It also helped to give a nice appearance to the final fresh vegan sausage and the cooked product as well.

Sausage casings help to get the correct sausage shape into the product. In this developed vegan sausage, cellulose casings were used instead of natural casings because natural casings have an animal origin and plastic casings were not used after considering environmental impact.

LDPE (Low-Density Polyethylene) vacuum packaging had to be used instead of biodegradable vacuum packaging, for the packaging of the vegan sausage in the development stage, mainly because of the high price of biodegradable vacuum packaging.

\section{Preliminary Studies}

Young green jackfruit to mushroom ratio in the sausage, was decided according to the web diagram (Figure 2) and the results of the Freidman test. There was no significant difference in colour between all the ratios $(\mathrm{p}>0.05)$ and there was a significant difference in odour, texture, taste and overall acceptability between the ratios $(p<0.05)$. According to the mean rank values of the Freidman test and the web diagram, 60:40 young green jackfruit to mushroom ratio was chosen to prepare product prototypes.

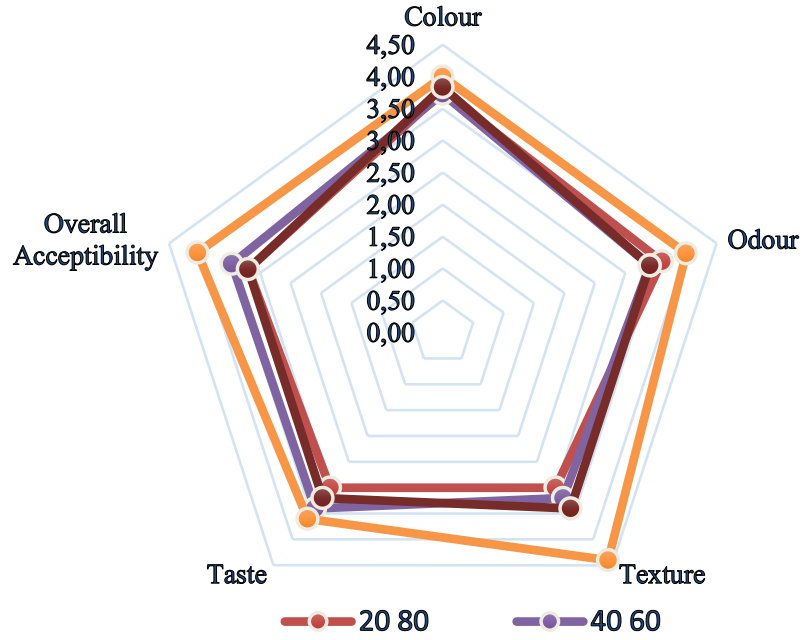

Figure 2 Web diagram for the sensory evaluation of selecting young green jackfruit to mushroom ratio

\section{Preparation of Product Prototypes}

Several final product characteristics were developed using some experimental designs in the product prototype developing phase. To develop the formula mushrooms were used after cooking for 20 minutes and it helped to reduce the harsh taste observed when used uncooked mushrooms. As binders, the mixture of cornflour, rice flakes and wheat flour were used, and it gave a good binding quality. Coconut flour and breadcrumbs were used after sieving which helped to reduce the grainy mouthfeel in the final product. Generally, cellulose casings are not soaked in water, but in the developing stage, two experiments were carried out without soaking and after soaking. The sausage stuffed after soaking resulted in no bursting of sausages at the steaming stage. Using $1 \mathrm{~cm}$ diameter sausage casings over 1.5 $\mathrm{cm}$ casings helped to reduce the final diameter and good texture after frying the sausage.

\section{Product Formula Optimization}

The final vegan sausage formula was selected according to the test results of the Freidman test and the web diagram (Figure 3).
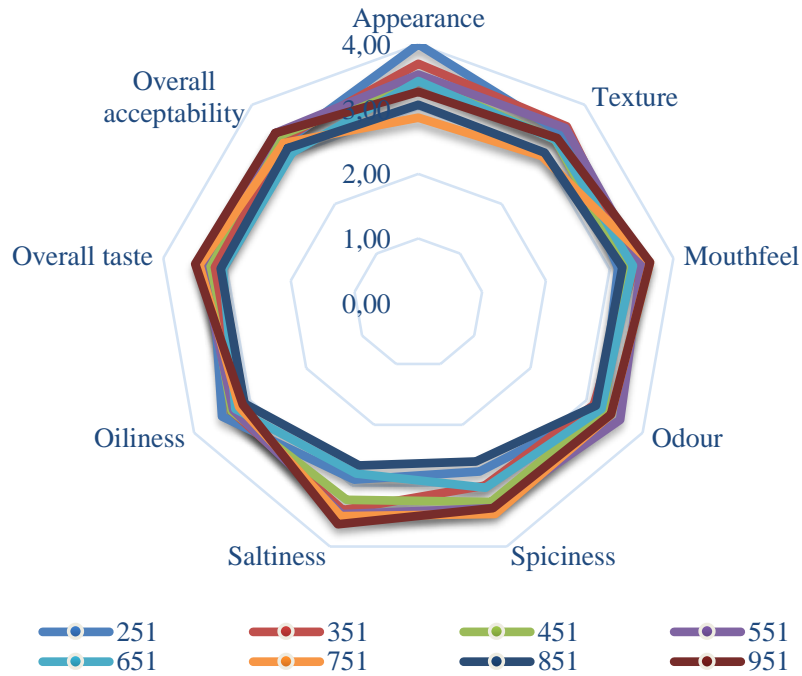

Figure 3 Web diagram for the sensory evaluation of vegan sausage formula optimization

There was no significant difference in texture, mouthfeel, odour, oiliness, overall taste, and overall acceptance between 8 samples $(p>0.05)$ and there was a significant difference in appearance, spiciness, and saltiness $(\mathrm{p}<0.05)$. According to the mean rank values, sample 951 was the best sample selected by the sensory panel. The sample labelled as 951 was the sample with the highest levels of salt, pepper, and coconut flour. After evaluating the above results sample 951 was chosen as the final formula. 

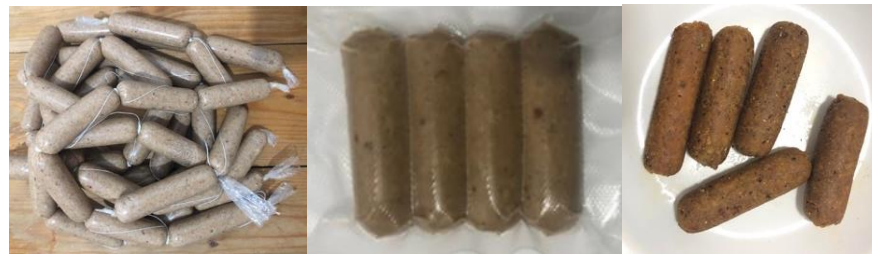

(b)

(c)

Figure.4: 4(a)Sausages after stuffing and tying, 4(b)Vacuum packed sausages,

4(c)Fried sausages

\section{Proximate Analysis}

Table 3 Proximate Composition of the developed vegan sausage

\begin{tabular}{ll}
\hline Parameter & Result $\mathbf{( g / 1 0 0 g})$ \\
\hline Moisture & $64.49 \pm 0.16$ \\
Ash & $2.62 \pm 0.18$ \\
Salt $(\mathrm{NaCl})$ & $1.85 \pm 0.07$ \\
Free Fat & $4.41 \pm 0.18$ \\
Total Fat & $5.94 \pm 0.25$ \\
Crude Protein & $3.95 \pm 0.30$ \\
Crude Fibre & $1.22 \pm 0.16$ \\
Total Carbohydrate & $21.78 \pm 0.38$ \\
\hline
\end{tabular}

\section{Microbiological Analysis}

Table 4 Microbiological analysis of the developed vegan sausage

\begin{tabular}{ll}
\hline Stage & Total Plate Count (cfu/g) \\
\hline Initial & $1.8 \times 10^{1}$ \\
After 2 weeks & $1.2 \times 10^{4}$ \\
After 4 weeks & $3.6 \times 10^{4}$ \\
$\begin{array}{l}\text { SLSI (Sri Lankan Standards Institue) } \\
\text { recommended levels }\end{array}$ & $<10^{6}$ \\
\hline
\end{tabular}

Within the first month, the microbiological limits were under the SLSI recommended levels and this can be considered as a shelf-life test.

\section{Cleaner Production Approach}

Initially, inputs and outputs generation with the production flow was studied.

Table 5 Material flow utilized per month

\begin{tabular}{lc}
\hline Material & Amount \\
\hline Input & \\
\hline Young green jackfruit & $120.9 \mathrm{~kg}$ \\
Mushroom & $54.5 \mathrm{~kg}$ \\
Water & $4.1 \mathrm{~m}^{3}$ \\
Other ingredients & $72.1 \mathrm{~kg}$ \\
Cellulose casings \& threads & $7 \mathrm{~kg}$ \\
\hline Output & \\
\hline Vegan sausage & $200 \mathrm{~kg}$ \\
\hline Liquid Waste & \\
\hline Wastewater & $4 \mathrm{~m}^{3}$ \\
\hline Solid waste & \\
\hline Peels and damaged parts & $42.6 \mathrm{~kg}$ \\
Remains in the mincer & $4 \mathrm{~kg}$ \\
Remains in the stuffer & $1 \mathrm{~kg}$ \\
Cellulose casings \& threads & $7 \mathrm{~kg}$ \\
\hline
\end{tabular}

The material flow (Table 5) was calculated assuming this production as a smallscale business in Sri Lanka. In the research stage, $10 \mathrm{~kg}$ of vegan sausages were prepared as the daily production and using that data monthly production was predicted considering 20 working days per month. Young green jackfruit generated about $35 \%-50 \%$ of peel and unwanted part waste. Mushroom generated very little waste in the raw material procurement stage. The residue parts remain in the mincer and stuffer was considered as waste.

Table 6 Water consumption per month

\begin{tabular}{lcc}
\hline Process & Input flow $\left(\mathbf{m}^{3}\right)$ & Output flow \\
\hline Process water & 0.1 & - \\
Non-process water - cleaning & 3.5 & 3.5 \\
Non-process water - domestic usage & 0.5 & 0.5 \\
\hline
\end{tabular}

In table 6 process water is the portion of water which directly used in the product. Non process water was used for cleaning of utensils and other domestic uses. The total amount of non-process water was considered as wastewater.

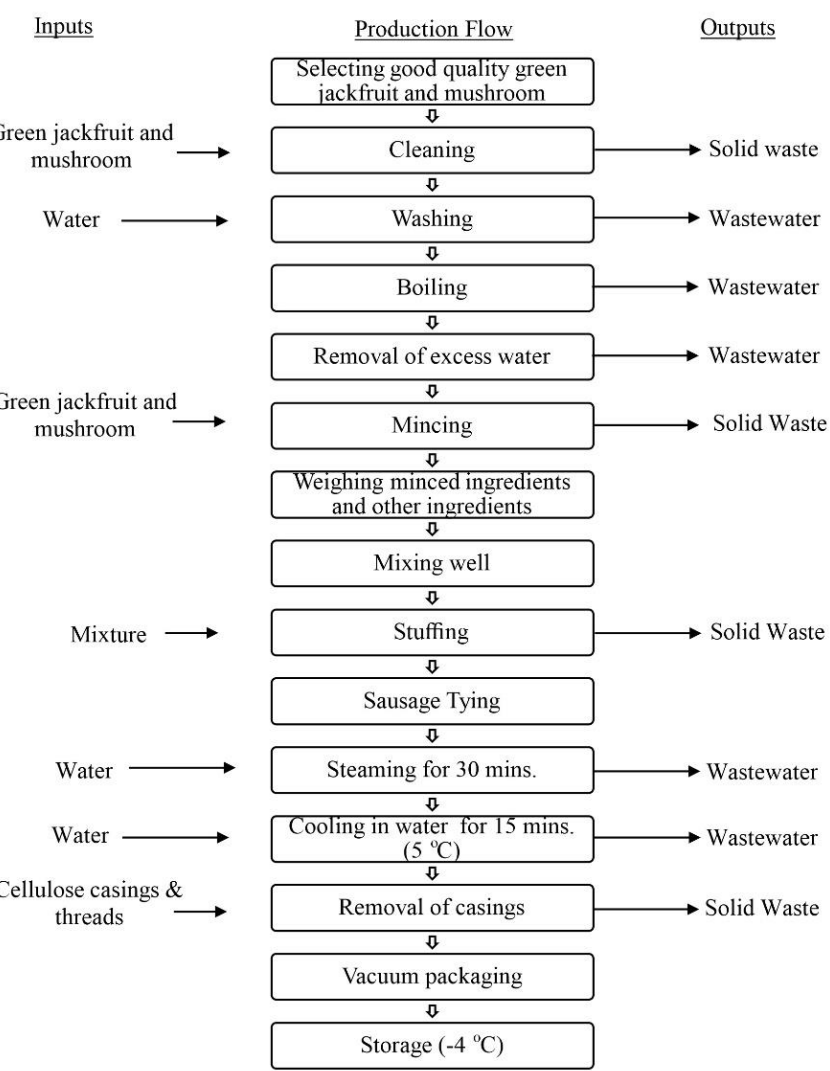

Figure 5 Input Output Material Flow

Table 7 Electricity/Energy consumption per month

\begin{tabular}{lll}
\hline Equipment & Operating hours/month & $\begin{array}{l}\text { Monthly } \\
\text { consumption } \\
(\mathbf{k W h})\end{array}$ \\
\hline 0.5 kWh Steamer & 60 & 30 \\
$1 \mathrm{kWh}$ Mincer & 20 & 20 \\
$0.1 \mathrm{kWh}$ Vacuum sealer & 40 & 4 \\
0.05 kWh Electronic balance & 20 & 1 \\
Deep Freezer & 720 & 30 \\
Other - Lights & - & 16 \\
\hline Total & & 101 \\
\hline
\end{tabular}

Monthly total electricity consumption was calculated as $101 \mathrm{kWh}$ (Table 7). The values were calculated by using available machinery manuals.

Table 8 Fuel (LPG) consumption per month

\begin{tabular}{lc}
\hline Equipment & Consumption (kg/month) \\
\hline Gas cooker & 12.5 \\
\hline
\end{tabular}

LPG was used to cook mushroom and young green jackfruit. Initially cooking was done using LPG but in Sri Lanka, LPG has a high emission factor. Considering that fact electric steamer which was used to steam sausage was replaced in cooking operation also.

Table 9 The Ecological Profile

\begin{tabular}{lccc}
\hline Entities & Amount & $\begin{array}{c}\mathbf{C O}_{2} \text { emission } \\
(\mathbf{k g} / \text { month })\end{array}$ & kg CO$/$ 1kg sausage \\
\hline Water & $4 \mathrm{~m}^{3}$ & 0.81 & 0.004 \\
Electricity & $101 \mathrm{kWh}$ & 58.58 & 0.293 \\
LPG & $12.5 \mathrm{~kg}$ & 34.12 & 0.171 \\
Solid waste & $54.6 \mathrm{~kg}$ & 42.04 & 0.210 \\
Wastewater & $4 \mathrm{~m}^{3}$ & 0.11 & 0.001 \\
\hline Total & & & 0.678 \\
\hline
\end{tabular}

According to the ecological profile (Table 9), total $\mathrm{CO}_{2}$ emission from $1 \mathrm{~kg}$ of sausage was $0.678 \mathrm{~kg} \mathrm{CO} / \mathrm{kg}$. The highest $\mathrm{CO}_{2}$ emission occurred due to electricity consumption. The below graph summarizes all the data obtained from the ecological profile. 


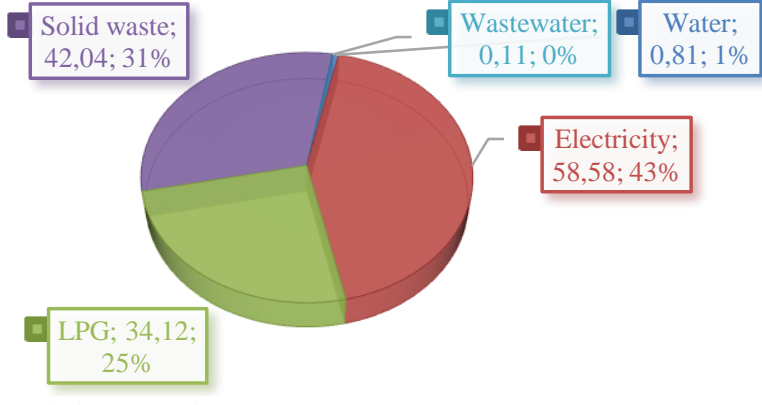

Figure $6 \mathrm{CO}_{2}$ emission according to sources

According to figure 6, electricity, solid waste and LPG generated a significant amount of $\mathrm{CO}_{2}$ into the atmosphere.

\section{Cleaner Production Options}

The main objective of a cleaner production assessment was to reduce the environmental impact during the lifecycle of the vegan sausage. Several cleaner production options were followed to reduce the above discussed impact. As a very basic step, good housekeeping practices were implemented. Also, by developing an organized operation, energy waste and unexpected waste generation were reduced. Switching off unwanted lights and switching off electrical equipmen when not in use helped to reduce the electricity consumption of the operation. Water consumption was reduced by implementing a foot-operated valve. It helped to open the water flow when only it requires.

Generally, the solid waste contains biodegradable and non-degradable material, but in this production, non-degradable material was used at a very low amount. Also, waste segregation was done to increase the ability of recycling. First In First Out (FIFO) method was used to reduce any waste generation from raw materials The remaining raw materials in the mincer after mincing operation was ground using a separate grinder and used in the production. When selecting raw materials, quality parameters were checked and with that, the generation of waste was reduced at the initial stage and it helped to optimize the production process as well.

Table 10 Reduced $\mathrm{CO}_{2}$ Emission

\begin{tabular}{|c|c|c|c|}
\hline Entities & Amount & $\begin{array}{lr}\begin{array}{l}\text { Estimated } \\
\text { emission } \\
(\mathrm{kg} / \text { month) }\end{array} & \begin{array}{r}\mathrm{CO}_{2} \\
\text { reduction }\end{array}\end{array}$ & $\mathrm{kg} \mathrm{CO}_{2} / 1 \mathrm{~kg}$ sausage \\
\hline Water & $0.5 \mathrm{~m}^{3}$ & 0.10 & 0.0005 \\
\hline Electricity & $5 \mathrm{kWh}$ & 2.90 & 0.0145 \\
\hline LPG & $12.5 \mathrm{~kg}$ & 34.12 & 0.1706 \\
\hline Solid waste & $4 \mathrm{~kg}$ & 3.08 & 0.0154 \\
\hline Wastewater & $0.5 \mathrm{~m}^{3}$ & 0.01 & 0.00005 \\
\hline Total & & 40.21 & 0.20105 \\
\hline
\end{tabular}

Table 10 shows the estimated $\mathrm{CO}_{2}$ reduction after implementing cleaner production options. It shows that $40.21 \mathrm{~kg}$ of $\mathrm{CO}_{2}$ emission can be reduced per month and $0.201 \mathrm{~kg}$ of $\mathrm{CO}_{2}$ emission can be reduced per $1 \mathrm{~kg}$ of sausage. The total $\mathrm{CO}_{2}$ emission from producing $1 \mathrm{~kg}$ of sausage was reduced from $0.678 \mathrm{~kg} \mathrm{CO}_{2} / \mathrm{kg}$ to $0.477 \mathrm{~kg} \mathrm{CO} / \mathrm{kg}$ which can be considered as a significant $\mathrm{CO}_{2}$ reduction in the production. In the global context raw sausage production emitts $8 \mathrm{~kg} \mathrm{CO}_{2} \mathrm{e} / \mathrm{kg}$ (Grabolle \& Loitz, 2007) which is very higher than this kind of small scale vegan sausage production.

\section{CONCLUSION}

The main objective of this research was to develop a sausage for the vegan community using young green jackfruit, mushrooms and coconut flour as an environmentally friendly and sustainable product promoting cleaner production approach. Based on the results of the study, it can be concluded that an environmentally friendly, vegan product can be developed using a cleaner production approach. Also, a sausage product can be developed without using soy or its derivatives as binders. Coconut flour can be used up to $3.2 \%$ without changing product attributes. Through implementing cleaner production options, negative environmental impacts of the developed vegan sausage can be reduced. After applying cleaner production options, the total $\mathrm{CO}_{2}$ emission from producing $1 \mathrm{~kg}$ of the sausage was able to reduce from $0.678 \mathrm{~kg} \mathrm{CO} / \mathrm{kg}$ to $0.477 \mathrm{~kg} \mathrm{CO} / \mathrm{kg}$. Since this sausage was developed using $100 \%$ plant-based ingredients using cleaner production techniques, and no preservative or artificial flavours were used, this can be considered as a $100 \%$ vegan product that is perfectly suited for the vegan community.

\section{REFERENCES}

Awanthi, M. G. G., \& Navaratne, C. M. (2018). Carbon Footprint of an Organization: A Tool for Monitoring Impacts on Global Warming. Procedia Engineering, 212, 729-735. https://doi.org/10.1016/j.proeng.2018.01.094

Balasooriya, L. B. A. U. (2008). Development of Soy Based Vegetarian Sausage [University of Sri Jayewardenepura] https://doi.org/10.31357/fapsmst.2008.00444

Balasooriya, L. B. A. U., Wickramasinghe, I., \& Bamunuarachchi, A. (2011). Development of a vegetarian blended sausage. Proceedings of the 67th Annual Sessions.

https://www.researchgate.net/publication/346470357_Development_of_a_vegeta rian_blended_sausage

Central Environmental Authority Sri Lanka. (2006). Instruction manual for calculation of wastewater discharge fees for industries. https://core.ac.uk/download/pdf/52175201.pdf

De Medeiros, J. F., Ribeiro, J. L. D., \& Cortimiglia, M. N. (2014). Success factors for environmentally sustainable product innovation: A systematic literature review. Journal of Cleaner Production, 65, 76-86. https://doi.org/10.1016/j.jclepro.2013.08.035

Fitzherbert, E. B., Struebig, M. J., Morel, A., Danielsen, F., Brühl, C. A., Donald, P. F., \& Phalan, B. (2008). How will oil palm expansion affect biodiversity? Trends in Ecology and Evolution, 23(10), 538-545. https://doi.org/10.1016/j.tree.2008.06.012

Grabolle, A., \& Loitz, T. (2007). Pendos CO2-Zähler. Pendo. https://timeforchange.org/eat-less-meat-co2-emission-of-our-food

Gunathilake, K. D. P. P., Yalegama, C., \& Kumara, A. A. N. (2009). Use of coconut flour as a source of protein and dietary fiber in wheat bread. Asian Journal of Food and Agro-Industry, 2(03), 382-391. https://www.researchgate.net/publication/235199278 Use of coconut flour_as a source of protein and dietary fibre in wheat bread

Hossain, S. (2016). Incorporation of Coconut Flour in Plain Cake and Investigation of the Effect of Sugar and Baking Powder on Its Baking Quality. International Journal of Nutrition and Food Sciences, 5(1), 31 https://doi.org/10.11648/j.ijnfs.20160501.15

Jayathilake, W. . (2008). Development of mushroom based sausage [University of Sri Jayawardenepura]. https://doi.org/10.31357/fapsmst.2008.00437

Liyanage, R. (2015). Development of a non-meat vegetable based sausage using locally available raw materials. Proceedings of the 71st Annual Sessions. http://dr.lib.sjp.ac.lk/handle/123456789/1976?mode=simple

Melina, V., Craig, W., \& Levin, S. (2016). Position of the Academy of Nutrition and Dietetics: Vegetarian Diets. Journal of the Academy of Nutrition and Dietetics, 116(12), 1970-1980. https://doi.org/10.1016/j.jand.2016.09.025

Ministry of Mahaweli Development \& Environment. (2016). A Guide for Carbon Footprint Assessment. The Climate Change Secretariat, Ministry of Mahaweli Development and Environment http://www.climatechange.lk/Documents/A_Guide_for_Carbon_Footprint_Asses sment.pdf

Nilson, L., Persson, P. O., Ryden, L., Darozhka, S., \& Zaliauskiene, A. (2007). The Environmental Management Book Series Cleaner Production - Technologies and Tools for Resource Efficient Production. In Environmental Management. https://www.uzwater.ktu.lt/index.php/download-files/compendia-and-

textbooks/module-a-environmental-science/152-environmental-managementsystems-book-2/file

Pauli, G. (1997). Zero emissions: The ultimate goal of cleaner production. Journal of Cleaner Production, 5(1-2), 109-113. https://doi.org/10.1016/s09596526(97)00013-9

Rahim, R., \& Raman, A. A. A. (2015). Cleaner production implementation in a fruit juice production plant. Journal of Cleaner Production, 101, 215-221. https://doi.org/10.1016/i.jclepro.2015.03.065

Ranasinghe, R. A. S. N., Maduwanthi, S. D. T., \& Marapana, R. A. U. J. (2019) Nutritional and Health Benefits of Jackfruit (Artocarpus heterophyllus Lam.): A Review. International Journal of Food Science, 2019. https://doi.org/10.1155/2019/4327183

Ruby, M. B. (2012). Vegetarianism. A blossoming field of study. Appetite, 58(1), 141-150. https://doi.org/10.1016/j.appet.2011.09.019

Sánchez-Machado, D. I., López-Cervantes, J., López-Hernández, J., \& PaseiroLosada, P. (2004). Fatty acids, total lipid, protein and ash contents of processed edible seaweeds. Food Chemistry, 85(3), 439-444. https://doi.org/10.1016/j.foodchem.2003.08.001

Saswattecha, K., Kroeze, C., Jawjit, W., \& Hein, L. (2015). Assessing the environmental impact of palm oil produced in Thailand. Journal of Cleaner Production, 100, 150-169. https://doi.org/10.1016/j.jclepro.2015.03.037

Schrier-Uijl, A. P., Silvius, M., Parish, F., Lim, K. H., Rosediana, S., \& Anshari, G. (2013). Environmental and Social Impacts of Oil Palm Cultivation on Tropical Peat-A Scientific Review Kalimantan Wetland and Climate Change Studies (KWACS) View project. April, 1-73. https://www.researchgate.net/publication/260058806

Sivakami, P. L., \& Sarojini, K. S. (2013). Formulation of Value Added Biscuits Using Defatted Coconut Flour. American Journal of Food Technology, 8, 207- 
212. https://doi.org/10.3923/ajft.2013.207.212

Sri Lanka Sustainable Energy Authority. (2017a). National Energy. http://www.energy.gov.lk/ODSM/Carbon-Footprint.html

Sri Lanka Sustainable Energy Authority. (2017b). Sri Lanka Energy Balance. http://www.energy.gov.lk/images/energy-balance/energy-balance-2017.pdf

Sridevi, S., \& Sarojini K.S. (2013). Biscuits formulation defatted coconut flour AJFT2013. American Journal of Food Technology, 8(3), 207-212. https://doi.org/10.3923/ajft.2013.207.212

Thrane, M., Paulsen, P. V., Orcutt, M. W., \& Krieger, T. M. (2017). Soy Protein: Impacts, Production, and Applications. In Sustainable Protein Sources (pp. 2345). Elsevier Inc. https://doi.org/10.1016/B978-0-12-802778-3.00002-0

World Economic Forum. (2020). Why sustainable products are a win-win for all of us. https://www.weforum.org/agenda/2018/05/sustainable-products-good-forthe-world-or-expensive-hype/

World Wildlife Fund. (2020). Soy | Industries | WWF. https://www.worldwildlife.org/industries/soy

Yi, H., Kim, J., Hyung, H., Lee, S., \& Lee, C. H. (2001). Cleaner production option in a food (Kimchi) industry. Journal of Cleaner Production, 9(1), 35-41. https://doi.org/10.1016/S0959-6526(00)00029-9

Żbikowska, A., Kowalska, M., \& Stauffer, C. (2020). Fats and Oils in Bakery Products (pp. 1-27). https://doi.org/10.1002/047167849X.bio075.pub2 